\title{
PERMASALAHAN PENUNTUTAN TERHADAP PELAKU PENYALAH GUNA NARKOTIKA DI WILAYAH HUKUM KEJAKSAAN NEGERI PADANG*
}

\author{
Rikhi Benindo Maghaz \\ Kejaksaan Republik Indonesia \\ Jl. Sultan Hasanuddin No. 1 Kebayoran Baru Jakarta Selatan \\ e-mail: rikhi.bm@gmail.com
}

\begin{abstract}
In the case handling of narcotics abuse, the public prosecutor at the Padang District Attorney's Office only proceed articles that had been suspected by the investigator, without proving accurately the status of the narcotics abuser. This research is aiming to understand the handling of narcotics abuse and its issues during the prosecution process at the Padang District Attorney's Office. This research is using empirical normative research methodology. Based on the research, the public prosecutor at the Padang District Attorney's Office did not precisely investigate and probe material evidence related to the status of the perpetrators of narcotics abuse. As a result, in indictment letter, the case of narcotics abuses always being overlaid with the harsher indictment articles, namely Article 111, 112, or 114 of Law Number 35 of 2009, which detention be applicable to the perpetrators. Supposing only a single indictment of article 127 is applied, the perpetrator of the narcotics abuse shall not be detained as stipulated in Article 21 paragraph (4) of KUHAP. This condition is clearly detrimental to the narcotics abuser, especially those people in addiction or victims of narcotics abuse, where they should be placed at the Rehabilitation Institute. Due to the absence of public prosecutor's meticulous attempt in probing material evidence related to the status of the perpetrators of narcotics abuse, it may cause false sentence declared by the judge.
\end{abstract}

Keywords: Prosecution; Criminal Acts; Abuse; Narcotics.

\begin{abstract}
Abstrak
Dalam penanganan perkara tindak pidana penyalahgunaan narkotika, penuntut umum pada Kejaksaan Negeri Padang hanya melanjutkan pasal-pasal yang sudah disangkakan penyidik, tanpa membuktikan dengan cermat status pelaku penyalah guna narkotika. Penelitian ini bertujuan untuk mengetahui penanganan perkara tindak pidana narkotika dan permasalahan pelaksanaan penuntutan perkara tindak pidana penyalahgunaan narkotika di Kejaksaan Negeri Padang. Penelitian ini menggunakan metodologi penelitian normatif empiris. Berdasarkan hasil penelitian, penuntut umum pada Kejaksaan Negeri Padang tidak meneliti dan menggali bukti-bukti materil mengenai status pelaku penyalah guna narkotika, sehingga pada surat dakwaan, selalu dilapis dengan dakwaan pasal yang ancaman pidananya lebih berat yakni Pasal 111, Pasal 112 maupun Pasal 114 Undang-undang Nomor 35 Tahun 2009, dengan alasan untuk dapat diterapkan penahanan kepada pelaku, karena apabila hanya diterapkan dakwaan tunggal Pasal 127, maka pelaku tindak pidana penyalah guna narkotika tidak dapat ditahan sebagaimana ketentuan Pasal 21 ayat (4) KUHAP, hal ini jelas merugikan pelaku penyalah guna narkotika, terutama bagi pecandu atau korban penyalahgunaan, sebab terhadap mereka seharusnya ditempatkan di Lembaga Rehabilitasi. Dengan tidak adanya upaya penuntut umum untuk menggali bukti-bukti materil mengenai status pelaku penyalah guna narkotika, akan berdampak pada putusan hakim yang tidak tepat.
\end{abstract}

Kata Kunci : Penuntutan; Tindak Pidana; Penyalah Guna; Narkotika.

\footnotetext{
* Naskah diterima: 23 Oktober 2018, direvisi: 27 November 2018, disetujui untuk terbit: 16 Februari 2019 Doi: $\underline{10.3376 / \text { jch.v4i2.104 }}$
} 


\section{PENDAHULUAN}

Undang-undang Nomor 35 Tahun 2009 Tentang Narkotika, menjelaskan Tindak Pidana Narkotika di dalam masyarakat telah menunjukan kecenderungan yang semakin kualitatif dengan korban yang meluas, terutama kalangan anak-anak, remaja dan generasi muda pada umumnya. Hal ini mendasari pemerintah telah melakukan perubahan dari aturan yang lama yakni Undangundang Nomor 22 Tahun 1997 Tentang Narkotika menjadi aturan yang baru yakni Undang-undang Nomor 35 Tahun 2009 Tentang Narkotika. Undang-undang Nomor 35 Tahun 2009 tidak saja mengatur mengenai aturan administrasi untuk ketersediaan narkotika sebagai zatzat menunjang dunia kesehatan, tetapi juga terdapat aturan pidana dalam hal pemberantasan terhadap tindak pidana narkotika. Dalam Undang-undang Nomor 35 Tahun 2009 ini juga dikenal dengan tindakan rehabilitasi medis dan sosial bagi pelaku tindak pidana penyalah guna narkotika yang dikategorikan sebagai pecandu.

Jenis-jenis narkotika di kalangan pecandu narkotika bervariasi pula, seiring dengan berkembangnya teknologi dan informasi (Gilang Fajar Shadiq, 2017: 36). Timbulnya penyalahgunaan narkotika adalah karena ketersediaan narkotika tidak hanya dalam hal kesehatan dan kepentingan ilmu pengetahuan, tetapi narkotika digunakan untuk kepentingan peredaran gelap narkotika. Secara sosiologis dampak dari peredaran gelap narkotika, adalah untuk menjaring sebanyak-banyaknya pelaku penyalah guna narkotika, sehingga dengan meningkatnya pelaku penyalah guna narkotika tersebut akan berdampak kepada kecanduan, dan akibat dari kecanduan tersebut akan membuat kebutuhan akan narkotika tersebut meningkat, kemudian para pelaku pengedar narkotika akan mendapatkan keuntungan yang besar dari bisnis peredaran gelap narkotika tersebut.

Menurut Sudarto, fungsi hukum pidana dibedakan menjadi dua yaitu fungsi umum dan fungsi khusus. Fungsi umum hukum pidana sama seperti fungsi hukum pada umumnya yaitu mengatur hidup kemasyarakatan atau menyelenggarakan tata tertib dalam masyarakat. Fungsi khusus hukum pidana adalah melindungi kepentingan hukum terhadap perbuatan yang hendak memperkosanya dengan sanksi berupa pidana (Eddy. OS. Hiariej, 2016: 34). Berdasarkan fungsi hukum yang dikemukakan Sudarto tersebut memberikan pemahaman, bahwa hukum pidana berfungsi sebagai instrumen mengatur hidup kemasyarakatan dan menyelenggarakan tata tertib dalam masyarakat, serta juga berfungsi memberikan perlindungan kepentingan hukum bagi pelaku yang melakukan perbuatan pidana tersebut, dengan cara memberikan sanksi berupa pidana bagi pelaku. Namun sebaliknya apabila pelaksanaan aturan hukum tidak 
Rikhi Benindo Maghaz: Permasalahan Penuntutan Terhadap Pelaku Penyalah Guna...

dilakukan oleh aparat penegak hukum dengan baik, maka fungsi hukum tidak akan tercapai.

Salah satu faktor penegakan hukum tersebut adalah aparat penegak hukum yang bertugas menerapkan aturan hukum yang berlaku. Memberikan pelayanan yang adil, memberikan perlindungan pada masyarakat dan para saksi, baik untuk kepentingan penyidikan, penuntutan maupun pada saat pemeriksaan di sidang pengadilan, serta penerapan sanksi pidana merupakan suatu operasionalisasi hukum (ius operatum) berhubungan dengan kewenangan penegakan hukum (Wisnu Djati Dewangga, 2014: 67). Salah satu aparat penegak hukum tersebut adalah pihak Kejaksaan selaku penuntut umum. Sebagaimana asas dominus litis, penuntut umum mempunyai peran sebagai pengendali perkara dalam penanganan suatu perkara tindak pidana.

Peran sentral penuntut umum dalam penanganan perkara pidana, terletak pada kewenangan penuntut umum dalam hal menyatakan berkas penyidikan perkara tersebut lengkap dan kemudian melakukan proses penuntutan perkara tersebut ke pengadilan. Dalam kasus narkotika, Kejaksaan mempunyai peran penting dalam melakukan penuntutan di sidang pengadilan untuk membuktikan kesalahan terdakwa. Terdakwa akan diputus bebas apabila terdapat kesalahan dalam menentukan bukti-bukti yang tidak cukup. Penuntutan yang tidak dilaksanakan dengan memenuhi buktibukti yang cukup atau tidak terpenuhinya Pasal 183 KUHAP akan berdampak kekaburan sehingga berdampak terhadap penghukuman terdakwa. (Cardiana Harahap, 2016: 15). Sebagai pihak yang hanya bertindak sebagai yang menyetujui dimulainya penyidikan dan menerima berita acara penyidikan, mengakibatkan penuntut umum hanya bertindak sebagai lembaga penuntutan. Yang paling dominan menjadi permasalahan dalam penuntutan adalah kendala-kendala yang dihadapi tentang fakta di lapangan, sebab secara langsung penuntut umum tidak bisa melakukan penyidikan terhadap kasus-kasus narkotika di lapangan (Tri Wahyu Kusuma Negara, 2017: 309).

Permasalahan penuntutan perkara Tindak Pidana Narkotika juga terjadi di Kejaksaan Negeri Padang. Untuk membahas permasalahan penanganan perkara tindak pidana narkotika pada Kejaksaan Negeri Padang, telah diambil sampel 3 perkara yang telah ditangani oleh penuntut umum pada Kejaksaan Negeri Padang, yakni pada perkara atas nama terdakwa Mardianto Pgl. Anto, Eka Tyza Effriyandi, SP Pgl. Andi dan Yohanes Salim Pgl. Aseng. Ketiga perkara ini dijadikan sampel penelitian ini, karena walaupun ada pembagian kategori pelanggar dalam tindak pidana penyalahgunaan narkotika, namun penuntut umum menerapkan pasal yang tidak seharusnya diberikan kepada pelaku penyalah guna narkotika. Penuntut umum hanya melanjutkan pasal-pasal yang sebelumnya sudah di sangkakan oleh penyidik, tanpa membuktikan dengan cermat status pelaku tindak pidana tersebut sebagai pecandu narkotika, yang 
kemudian hal itu berujung pada putusan pidana penjara oleh pengadilan (hakim). Seharusnya aparat penegak hukum dapat lebih jeli lagi melihat amanat Undangundang Nomor 35 Tahun 2009 dan regulasi lainnya yang mengatur tentang penanganan penyalah guna narkotika. Sudah jelas dikatakan dalam Pasal 54 Undang-undang Nomor 35 Tahun 2009 yang mengutamakan bahkan wajib hukumnya bagi pecandu dan korban penyalahgunaan narkotika untuk menjalani rehabilitasi medis dan rehabilitasi sosial, hal itu diperkuat lagi oleh Peraturan Pemerintah Republik Indonesia Nomor 25 Tahun 2011 Tentang Pelaksanaan Wajib Lapor Pecandu Narkotika. Peraturan pemerintah ini bertujuan untuk memenuhi hak pecandu narkotika dalam mendapatkan pengobatan dan/atau perawatan melalui rehabilitasi medis dan rehabilitasi sosial. Ketentuan dalam Peraturan Pemerintah Nomor 25 Tahun 2011 ini pun semestinya dijalankan pula oleh para aparat penegak hukum mengingat peraturan pemerintah termasuk dalam hirarki perundang-undangan.

Pada perkara penyalahgunaan narkotika, penuntut umum selalu mendakwa pelaku penyalah guna narkotika dengan ketentuan yang jauh lebih berat, yaitu dengan pasal 111 atau pasal 112 Undang-undang Nomor 35 Tahun 2009. Padahal ketentuan pidana untuk pelaku penyalah guna narkotika telah diatur pada Pasal 127 Undangundang Nomor 35 Tahun 2009 dengan ancaman pidana penjara paling lama 4 tahun, bahkan apabila pelaku penyalah guna narkotika tersebut adalah pecandu, maka hakim dapat memberikan putusan berupa rehabilitasi.

Karena belum ada kajian atau penelitian tentang hal ini sebelumnya, maka penulis tertarik untuk membahas hal ini, agar penanganan perkara tindak pidana penyalahgunaan narkotika dapat terlaksana sesuai dengan ketentuan yang berlaku. Adapun perumusan masalah dalam penulisan ini adalah: bagaimana penanganan perkara tindak pidana narkotika di Kejaksaan Negeri Padang dan bagaimana analisa terhadap pelaksanaan penuntutan perkara tindak pidana penyalah guna narkotika di Kejaksaan Negeri Padang?

\section{METODE PENELITIAN}

Penelitian ini merupakan penelitian hukum (legal research). Menurut $\mathrm{F}$. Sugeng Istanto, penelitian hukum adalah penelitian yang diterapkan atau diberlakukan khusus pada ilmu hukum. (F. Sugeng Istanto, 29: 2005). Dalam penelitian ini, pendekatan masalah yang akan digunakan adalah pendekatan normatif empiris (applied law research) yakni penggabungan antara pendekatan hukum normatif dengan adanya penambahan unsur empiris. Metode penelitian normatif-empiris bermula dari ketentuan hukum positif tertulis yang diberlakukan pada peristiwa hukum in concreto dalam masyarakat, sehingga dalam penelitiannya selalu terdapat dua tahap kajian (Abdulkadir Muhammad, 2004: 52), yaitu: 
Rikhi Benindo Maghaz: Permasalahan Penuntutan Terhadap Pelaku Penyalah Guna...

a. Tahap pertama, adalah kajian mengenai hukum normatif yang berlaku;

b. Tahap kedua, adalah penerapan pada peristiwa in concreto guna mencapai tujuan yang telah ditentukan. Penerapan tersebut dapat diwujudkan melalui perbuatan nyata dan dokumen hukum. Hasil penerapan akan menciptakan pemahaman realisasi pelaksanaan ketentuan hukum normatif yang dikaji telah dijalankan secara patut atau tidak.

\section{HASIL DAN PEMBAHASAN}

\section{Penanganan Perkara Tindak Pidana Narkotika Di Kejaksaan Negeri Padang}

Penuntut umum pada Kejaksaan Negeri Padang tidak pernah menempatkan Pasal 127 berdiri sendiri (dakwaan tunggal), tetapi selalu disertai atau dengan pasal lain, terutama pasal 111 (untuk jenis tanaman) atau pasal 112 (untuk jenis bukan tanaman) yang merupakan pasal yang mengatur sebagai pemilik, yang menyimpan atau yang menguasai narkotika. Untuk membahas permasalahan penanganan perkara tindak pidana narkotika pada Kejaksaan Negeri Padang, telah diambil sampel 3 perkara yang telah ditangani oleh penuntut umum pada Kejaksaan Negeri Padang, yakni pada perkara atas nama terdakwa Mardianto Pgl. Anto, Eka Tyza Effriyandi, SP Pgl. Andi dan Yohanes Salim Pgl. Aseng. Ketiga perkara ini dipilih, karena ketiga perkara tersebut memliki konstruksi kasus yang sama, namun dalam penanganannya, penuntut umum di Kejaksaan Negeri Padang ditangani dengan cara yang berbeda, hal ini berdampak kepada tuntutan pidana dan putusan pidana kepada pelaku.

\subsection{Perkara Atas Nama Mardianto Pgl. Anto}

Bahwa kasus posisi singkat perkara dengan terdakwa atas nama Mardianto Pgl. Anto ini adalah, awalnya pada hari Kamis tanggal 09 Februari 2017 sekira pukul 21.30 Wib terdakwa Mardianto Pgl. Anto mendatangi saudara Imam (DPO) dengan tujuan untuk membeli 1 paket narkotika jenis ganja yang terbungkus plastik putih, kemudian terdakwa membawa 1 paket ganja tersebut ke rumahnya, sesampai di rumahnya terdakwa mengambil daun ganja kering tersebut dan dicampur dengan tembakau pada 1 batang rokok merk Class Mild lalu ujungnya dibakar terdakwa. Kemudian terdakwa menghisap asapnya seperti orang merokok. Setelah itu terdakwa membagi 1 paket narkotika tersebut menjadi 4 paket ukuran sedang dan 3 paket ukuran kecil. Kemudian pada pukul 23.30 Wib datang anggota kepolisian dari Polresta Padang, dimana sebelumnya pihak Polresta Padang telah mendapatkan informasi dari masyarakat tentang perbuatan terdakwa tersebut. Pada saat itu anggota Polresta Padang langsung menggeledah rumah terdakwa, dari hasil penggeledahan ditemukan barang bukti ganja.

\begin{tabular}{|c|c|c|c|}
\hline & Dalam Berkas & Penyidikan & Perkara \\
\hline dari & Polresta & Padang & Nomor: \\
\hline
\end{tabular}


penyidik Polresta Padang dengan sangkaan Pasal 114 ayat (1) Undangundang Nomor 35 Tahun 2009 (sebagai pelaku yang membeli atau menerima narkotika golongan I), lalu Pasal 111 ayat (1) Undang-undang Nomor 35 Tahun 2009 (sebagai pelaku yang memiliki, menyimpan atau menguasai narkotika golongan I) dan Pasal 127 ayat (1) huruf a Undang-undang Nomor 35 Tahun 2009 (sebagai pelaku penyalah guna narkotika golongan I). Kemudian penuntut umum melimpahkan perkara tersebut ke Pengadilan Negeri Padang, dengan dakwaan berbentuk subsidaritas yakni Dakwaan Primair Pasal 114 ayat (1) Undang-undang Nomor 35 Tahun 2009, subsidiair Pasal 111 ayat (1) Undangundang Nomor 35 Tahun 2009, lebih subsidiair Pasal 127 ayat (1) huruf a Undang-undang Nomor 35 Tahun 2009.

Pada tahap pra penuntutan, penuntut umum yang meneliti berkas perkara ini, juga tidak memberikan petunjuk (P-19) kepada penyidik untuk mengungkap status penyalah guna narkotika dari terdakwa ini. Bahwa dengan kewenangan penuntut umum dalam meneliti berkas penyidikan perkara, seharusnya dapat melakukan pra penuntutan dengan mengembalikan berkas penyidikan perkara tersebut kepada penyidik Polresta Padang dengan petunjuk agar penyidik melengkapi bukti-bukti penyidikan dengan menelusuri status terdakwa Mardianto pgl. Anto, terutama dalam mengungkap keterlibatan terdakwa dalam peredaran gelap narkotika. Walaupun penuntut umum tidak memberikan petunjuk kepada penyidik untuk mengungkap pembuktian keterlibatan terdakwa Mardianto Pgl. Anto dalam peredaran gelap narkotika, namun demikian dalam surat dakwaan, penuntut umum tetap menerapkan Pasal 114 ayat (1) sebagai dakwaan primair. Jaksa Nazif Firdaus, sebagai penuntut umum dalam perkara ini, menilai penerapan Pasal 114 dalam dakwaan primair adalah berdasarkan alat bukti keterangan saksi Harry Akmal dan Dino Riki Revalino (kedua saksi merupakan anggota Polresta Padang yang menangkap terdakwa) serta keterangan terdakwa Mardianto pgl. Anto. Menurut Jaksa Nazif Firdaus, dengan adanya alat bukti yang menerangkan bahwa terdakwa telah menerima 1 (satu) paket narkotika jenis ganja dari saudara Imam (DPO) tersebut, dinilai telah tepat untuk menerapkan Pasal 114 tersebut sebagai dakwaan primair, walaupun tidak ada upaya untuk membuktikan secara materiil mengenai keterlibatan terdakwa dalam peredaran gelap narkotika.

Bahwa pada Dakwaan Subsidiair, penuntut umum menerapkan Pasal 111 ayat (1). Pasal 111 tersebut diterapkan karena berdasarkan keterangan saksi-saksi dari Polresta Padang dan saksi dari warga yang menyaksikan penangkapan terdakwa serta didukung dengan keterangan terdakwa Mardianto pgl. Anto, didapatkan fakta bahwa barang bukti narkotika jenis ganja tersebut ada dalam penguasaan terdakwa, disimpan terdakwa dalam kotak rokok merk Class Mild dan diletakkan terdakwa di atas meja ruang tamu di rumahnya. Selanjutnya pada dakwaan 
Rikhi Benindo Maghaz: Permasalahan Penuntutan Terhadap Pelaku Penyalah Guna...

lebih subsidiair, penuntut umum menerapkan Pasal 127, hal ini berdasarkan fakta-fakta penyidikan yang diperoleh dari alat bukti keterangan saksisaksi dari anggota Polresta Padang yang menangkap terdakwa, saksi warga yang menyaksikan penangkapan terhadap terdakwa dan dari keterangan terdakwa, serta alat bukti surat berupa Surat Keterangan Hasil Pemeriksaan Urine dari Rumah Sakit Bhayangkara Padang Nomor: SKHP/568/II/RS. Bhayangkara tanggal 10 Februari 2017 menyatakan bahwa urine terdakwa positif mengandung THC (ganja).

Bahwa alat bukti yang diajukan penuntut umum ke persidangan yakni saksi Harry Akmal (anggota Polresta Padang yang melakukan penangkapan) saksi Anwar (anggota Polresta Padang yang melakukan penangkapan), dan saksi Yetimar Pgl. Yet (Ketua RT yang menyaksikan penggeledahan dan penangkapan terdakwa), kemudian dengan alat bukti surat berupa Berita Acara Analisis Laboratorium Forensik Polri Cabang Medan Nomor: 1767/NNF/2017 yang menerangkan bahwa barang bukti berupa daun ganja kering yang ditemukan saat terdakwa ditangkap, positif mengandung ganja, lalu alat bukti surat Berita Acara Penimbangan Barang Bukti dari PT. Pegadaian Cabang Padang Nomor: 125/023100/II/2017 tanggal 16 Februari 2017 yang menerangkan total barang bukti narkotika jenis ganja yang ditemukan dari terdakwa adalah seberat 9,19 gram, serta alat bukti surat berupa Surat Keterangan Hasil
Pemeriksaan Urine Nomor: SKHP/568/II/RS. Bhayangkara tanggal 10 Februari 2017 menyatakan bahwa urine terdakwa positif mengandung THC (ganja), alat bukti keterangan terdakwa yang mengakui barang bukti tersebut adalah miliknya, serta berdasarkan barang bukti yang ditemukan dari terdakwa saat penangkapan.

Bahwa berdasarkan alat bukti yang diajukan ke persidangan, penuntut umum membuktikan dakwaan lebih subsidiair Pasal 127 ayat (1) huruf a. Analisa yuridis penuntut umum menuntut dakwaan lebih subsidiair, adalah karena berdasarkan fakta persidangan, didapatkan fakta bahwa barang bukti narkotika jenis ganja yang ditemukan saat penangkapan terdakwa adalah sisa pakai dari terdakwa dan akan digunakan terdakwa untuk dirinya sendiri, bukan untuk dijual lagi, hal ini diperkuat dengan barang bukti berupa 3 (tiga) lembar kertas vapir yang merupakan alat untuk melinting ganja. Alat bukti lain yang membuktikan terdakwa sebagai penyalah guna narkotika adalah Surat Keterangan Hasil Pemeriksaan Urine dari Rumah Sakit Bhayangkara Padang yang menyatakan urine terdakwa positif mengandung THC (ganja). Analisa yuridis penuntut umum yang menyatakan, perbuatan terdakwa tidak terbukti melanggar Dakwaan Primair Pasal 114 ayat (1) adalah karena perbuatan terdakwa tidak didukung alat bukti yang cukup sebagaimana Pasal 184 KUHAP, karena tidak ada saksi-saksi dan alat bukti lainnya yang menyatakan 
terdakwa membeli atau menerima narkotika jenis ganja tersebut.

Di persidangan tersebut, penuntut umum menuntut terdakwa dengan dakwaan lebih subsidiair Pasal 127 ayat (1) sebagai pelaku penyalah guna narkotika golongan I dengan tuntutan selama 2 (dua) tahun penjara. Bahwa kemudian majelis hakim pada Pengadilan Negeri Padang yang menangani perkara tersebut memutus dengan dakwaan pasal yang sama, namun dengan putusan pidana badan selama 1 (satu) tahun dan 6 (enam) bulan penjara.

\subsection{Perkara Atas Nama Eka Tyza Effriyandi, SP Pgl. Andi}

Bahwa kasus posisi singkat perkara dengan terdakwa atas nama Eka Tyza Effriyandi, SP Pgl. Andi, adalah pada hari Rabu tanggal 20 Juli 2016 sekitar pukul $13.00 \mathrm{Wib}$, terdakwa menghubungi sdr. Ganteng (Daftar Pencarian Orang/DPO). Terdakwa menanyakan paket narkotika jenis ganja kepada sdr. Ganteng (DPO), saat itu sdr. Ganteng menjawab masih ada, setelah itu sdr. Ganteng langsung menyuruh terdakwa untuk menunggu di Jalan Simpang Jakarta, dan tidak lama setelah itu sdr. Ganteng datang dan terdakwa langsung menyerahkan uang sebanyak Rp.30.000,- (tiga puluh ribu rupiah) kepada sdr. Ganteng dan pada saat itu sdr. Ganteng langsung menyerahkan 1 (satu) paket kecil narkotika jenis ganja, kemudian terdakwa membawa ganja tersebut pulang kerumahnya di Jalan Semarang Blok I No.04 Wisma Indah IV Siteba Kelurahan Surau Gadang Kecamatan Nanggalo Kota Padang.
Sesampainya di rumah, terdakwa langsung menggunakan narkotika jenis dengan cara mencampurnya dengan tembakau, lalu sisa ganja tersebut disimpan terdakwa kedalam kaleng rokok merk Gudang Garam Surya lalu diletakkan diatas meja makan. Sekitar pukul 15.30 Wib saksi Ahmad Drajat Bara Putra Pgl. Jeki datang kerumah terdakwa. Kemudian sekitar pukul 17.45 Wib saksi Ahmad Drajat Bara Putra Pgl. Jeki dan saksi Muhammad Riza Pgl. Adek melinting ganja kering yang sebelumnya disimpan oleh terdakwa di dalam kaleng rokok Gudang Garam, lalu pada saat saksi Ahmad Drajat Bara Putra Pgl. Jeki dan saksi Muhammad Riza Pgl. Adek melinting ganja kering, datang aparat kepolisian melakukan penangkapan terhadap terdakwa bersama dengan saksi Ahmad Drajat Bara Putra Pgl. Jeki. Pada saat penggeledahan, aparat kepolisian menemukan barang bukti berupa 1 (satu) batang rokok Sampoerna yang berisikan daun, biji ganja kering yang dicampur tembakau yang ditemukan di atas meja dalam kamar rumah, 1 (satu) batang rokok $U$ Bold yang berisikan daun, biji ganja kering yang telah dicampur dengan tembakau diatas meja ruang keluarga, 2 (dua) buah potongan ranting ganja kering yang masih ada biji, daunya ditemukan dalam kaleng rokok Gudang Garam Surya yang terletak di anak tangga rumah. Selanjutnya terdakwa beserta barang bukti dibawa ke Polresta Padang guna pemeriksaan lebih lanjut. Kemudian dilakukan pemeriksaan terhadap urine terdakwa, dan berdasarkan Surat Keterangan Hasil Pemeriksaan Urine 
Rikhi Benindo Maghaz: Permasalahan Penuntutan Terhadap Pelaku Penyalah Guna...

Nomor:

SKHP/60/VII/2016/RS.

Bhayangkara tanggal 20 Juli 2016 yang dibuat dan ditandatangani oleh dr. Adli Dokter Pemerintah pada Rumah Sakit Bhayangkara Padang, didapatkan hasil bahwa urine terdakwa positif mengandung THC (ganja). Berdasarkan keterangan terdakwa Eka Tyza Effriyandi, SP Pgl. Andi pada poin 16 BAP penyidikan perkara tersebut, menyatakan bahwa barang bukti narkotika jenis ganja yang ia miliki dan simpan tersebut adalah untuk dikonsumsinya sendiri, dan ia telah mengonsumsi narkotika jenis ganja sejak tahun 2014 atau sejak 2 tahun sebelum ditangkap dalam perkara ini.

Dalam berkas penyidikan perkara, penyidik tidak menerapkan ketentuan Pasal 54, Pasal 103, dan Pasal 127 ayat (2) dan (3) Undang-undang Nomor 35 Tahun 2009 untuk menentukan kategori penyalah guna dari terdakwa Eka Tyza Effriyandi, SP Pgl. Andi. Hal ini mengakibatkan status terdakwa tersebut tidak diketahui, apakah termasuk penyalah guna biasa, pencandu atau korban penyalahgunaan narkotika. Bahwa dengan kewenangan penuntut umum dalam meneliti berkas penyidikan perkara, seharusnya mengembalikan berkas penyidikan perkara tersebut kepada penyidik Polresta Padang dengan petunjuk agar melengkapi bukti-bukti penyidikan dengan menelusuri status terdakwa Eka Tyza Effriyandi, SP Pgl. Andi, apakah termasuk penyalah guna narkotika biasa, pecandu atau korban penyalahgunaan narkotika, sehingga ketentuan Pasal 54, Pasal 103, dan Pasal
127 ayat (2) dan (3) Undang-undang Nomor 35 Tahun 2009 dapat diterapkan dalam perkara ini.

Berdasarkan keterangan dari penuntut umum perkara ini, tidak diberikannya petunjuk kepada penyidik untuk menentukan status terdakwa, adalah karena adanya surat dari Kepala Badan Narkotika Nasional Provinsi (BNNP) Sumatera Barat Nomor: R/267/IX/Ka/RH.00.00/2016/BNP-SB tanggal 13 September 2016. Dalam surat tersebut, pada pokoknya menyatakan hasil rekomendasi asesment terpadu terhadap terdakwa Eka Tyza Effriyandi, SP Pgl. Andi, secara medis menyebutkan terdakwa adalah pecandu narkotika dan tim hukum BNNP menyatakan terdakwa tidak ada indikasi terlibat dalam jaringan peredaran gelap narkotika, sehingga Tim Asessment Terpadu BNNP Sumatera Barat merekomendasikan terdakwa Eka Tyza Effriyandi, SP Pgl. Andi untuk dilakukan rehabilitasi di dalam Lembaga Rehabilitasi RSJ HB Sa'anin Padang sambil menunggu proses hukum. Atas dasar surat rekomendasi dari BNNP Sumatera Barat tersebut, penuntut umum menilai terdakwa Eka Tyza Effriyandi, SP Pgl. Andi tidak perlu dikumpulkan alat bukti lain, seperti dari keterangan saksi, ahli atau terdakwa untuk mengetahui status terdakwa, karena telah jelas terdakwa merupakan sebagai pecandu narkotika.

Dengan adanya bukti permulaan yang membuktikan bahwa terdakwa Eka Tyza Effriyandi, SP Pgl. Andi secara nyata sebagai pelaku pelaku penyalahgunaan 
narkotika dengan status pecandu, seharusnya penuntut umum dalam membuat surat dakwaan dapat menerapkan dakwaan tunggal yakni Pasal 127 ayat (1) Undang-undang Nomor 35 Tahun 2009 Tentang Narkotika, namun demikian dalam surat dakwaan perkara ini, penuntut umum tetap melapis perkara ini dengan dakwaan subsidaritas Pasal 114 ayat (1), subsidiair Pasal 111 ayat (1), lebih subsidiair Pasal 127 ayat (1) huruf a Undang-undang Nomor 35 Tahun 2009.

Bahwa sebagaimana hasil rekomendasi asessment Tim BNNP Sumatera Barat dalam Surat Kepala Badan Narkotika Nasional Provinsi Sumatera Barat Nomor : R/267/IX/Ka/RH.00.00/2016/BNNP-SB tanggal 13 September 2016 yang pada pokoknya menyatakan Eka Tyza Effriyandi, SP Pgl. Andi tidak ada indikasi terlibat jaringan peredaran gelap narkotika, serta melihat barang bukti narkotika jenis ganja yang berbentuk lintingan dengan tembakau sebatang rokok, seharusnya terhadap terdakwa Eka Tyza Effriyandi, SP Pgl. Andi, tidak tepat diterapkan Pasal 114 ayat (1), maupun Pasal 111 ayat (1) di dalam dakwaannya. Hal ini karena bukti-bukti yang terdapat dalam berkas penyidikan perkara ini, telah nyata menunjukkan terdakwa Eka Tyza Effriyandi, SP Pgl. Andi sebagai pecandu narkotika, bahkan Tim Asesment BNNP Sumatera Barat merekomendasikan terdakwa Eka Tyza Effriyandi, SP Pgl. Andi untuk ditempatkan di Lembaga Rehabilitasi, artinya dalam surat dakwaan terdakwa Eka Tyza Effriyandi, SP Pgl.
Andi lebih tepat diterapkan dakwaan tunggal Pasal 127 ayat (1) huruf a sebagai pelaku penyalah guna narkotika golongan I.

Berdasarkan keterangan penuntut umum perkara ini, tidak diterapkannya dakwaan tunggal Pasal 127 ayat (1) huruf a dalam surat dakwaan, adalah karena untuk kepentingan penahanan terdakwa. Hal ini diterapkan karena Pasal 127 ayat (1) huruf a mempunyai ancaman paling lama penjara selama 4 tahun, sehingga apabila diterapkan dakwaan tunggal Pasal 127 ayat (1) huruf a, maka terhadap terdakwa tidak dapat dilakukan penahanan. Untuk dilakukan penahanan diperlukan pasal dakwaan yang mengandung ancaman 5 tahun penjara atau lebih, sehingga atas dasar inilah penuntut umum perkara ini menerapkan dakwaan Pasal 114 ayat (1) dan Pasal 112 ayat (1) dapat diterapkan kepada terdakwa.

Bahwa kemudian dalam pembuktian di persidangan, berdasarkan alat bukti tersebut, penuntut umum menuntut terdakwa dengan dengan Dakwaan Lebih Subsidiair Pasal 127 ayat (1) Undangundang Nomor 35 Tahun 2009 (sebagai pelaku penyalah guna narkotika golongan I) dengan tuntutan selama 1 (satu) tahun dan 6 (enam) bulan dengan memerintahkan kepada terdakwa untuk menjalani Rehabilitasi di Rumah Sakit Jiwa HB. Sa'anin Padang. Berdasarkan wawancara dengan penuntut umum perkara tersebut yakni Jaksa Ekky Rizky Asril alasan penuntut umum membuktikan Dakwaan Lebih Subsidiair 
Rikhi Benindo Maghaz: Permasalahan Penuntutan Terhadap Pelaku Penyalah Guna...

sebagai pelaku penyalah guna narkotika golongan I adalah karena sewaktu ditangkap terdakwa sedang menggunakan narkotika tersebut, selain itu berdasarkan alat bukti surat berupa Surat Kepala Badan Narkotika Nasional Provinsi Sumatera Barat Nomor: R/267/IX/Ka/RH.00.00/2016/BNNP-SB tanggal 13 September 2016, merekomendasikan terdakwa untuk dilakukan Rehabilitasi di dalam Lembaga Rehabilitasi RSJ HB Sa'anin Padang, atas hal inilah penuntut umum pada perkara ini menuntut terdakwa untuk menjalani rehabilitasi. Bahwa kemudian majelis hakim pada Pengadilan Negeri Padang yang menangani perkara tersebut memutus dengan dakwaan pasal yang sama, namun dengan putusan pidana badan selama 1 (satu) tahun penjara dengan masa rehabilitasi di dalam Lembaga Rehabilitasi RSJ HB Sa'anin Padang selama 6 (enam) bulan.

\subsection{Perkara Atas Nama Yohanes Salim pgl. Aseng bin Nurtanto Salim}

Bahwa kasus posisi singkat perkara ini adalah, pada hari Rabu tanggal 25 November 2015, saksi Syukri dan saksi Hengki Efendi yang merupakan anggota Satresnarkoba Polresta Padang mendapat informasi bahwa terdakwa melakukan penyalahgunaan narkotika. Kemudian saksi Syukri bersama anggota Satresnarkoba Polresta Padang mendatangi rumah terdakwa, sesampainya di rumah terdakwa anggota Satresnarkoba langsung melakukan penangkapan terhadap terdakwa yang sedang duduk di dalam rumahnya, lalu dilakukan

penggeledahan dan ditemukan 1 (satu) buah kotak rokok merk U Mild warna putih biru berisikan 1 (satu) paket besar shabu, 1 (satu) buah bong terbuat dari botol plastik berisikan air terpasang pipet kaca pirek dan karet kompeng, 1 (satu) buah mencis dan 1 (satu) buah kaca pirek di atas meja rumah terdakwa. Pada saat ditanyakan oleh petugas kepolisian, terdakwa mengakui bahwa semua barang bukti tersebut adalah milik dan dalam penguasaan terdakwa, kemudian petugas kepolisian melakukan penyitaan terhadap barang bukti yang ditemukan tersebut. Berdasarkan Berita Acara Penimbangan Nomor: 868/023100/2015 tanggal 2 Desember 2015 di PT Pegadaian (Persero) Cabang Terandam Padang barang bukti berupa 1 (satu) paket besar yang terbungkus plastik klep bening yang berisikan butiran kristal bening diduga narkotika jenis shabu dengan total berat bersih 4,09 gram dan Berita Acara Analisis Laboratorium Barang Bukti Narkotika No. Lab: 11358/NNF/2015 tanggal 8 Desember 2015 bahwa barang bukti tersebut Positif Metamfetamina dan terdaftar dalam Golongan I Nomor Urut 61 Lampiran I Undang-Undang Republik Indonesia No. 35 Tahun 2009.

Dalam Berkas Penyidikan $\begin{array}{r}\text { Perkara } \\ \text { dari Polresta Padang }\end{array}$ Nomor:
BP/126/XII/2015/Satresnarkoba tanggal
25 November 2015, terdakwa diajukan
oleh penyidik dengan pasal sangkaan
Pasal 114 ayat (1) Undang-undang Nomor
35 Tahun 2009, Pasal 112 ayat (1)
Undang-undang Nomor 35 Tahun 2009
dan Pasal 127 ayat (1) huruf a Undang-


undang Nomor 35 Tahun 2009. Kemudian perkara tersebut dinyatakan lengkap (P21) oleh penuntut umum. Selanjutnya penuntut umum melimpahkan perkara tersebut ke Pengadilan Negeri Padang dengan surat pelimpahan perkara acara pemeriksaan biasa, dengan dakwaan berbentuk subsidaritas yakni Dakwaan Primair Pasal 114 ayat (1) Undangundang Nomor 35 Tahun 2009, Subsidiair Pasal 112 ayat (1) Undang-undang Nomor 35 Tahun 2009, Lebih Subsidiair Pasal 127 ayat (1) huruf a Undang-undang Nomor 35 Tahun 2009.

Dalam Berita Acara Pemeriksaan (BAP) terdakwa Yohanes Salim pgl. Aseng bin Nurtanto Salim di tingkat penyidikan, menjelaskan bahwa terdakwa telah menjadi penyalah guna narkotika jenis shabu sejak tahun 2014 dan ia menjelaskan juga telah menggunakan narkotika jenis shabu untuk diri sendiri sebanyak lebih kurang 30 kali. Berkaitan dengan penerapan ketentuan Pasal 54, Pasal 103, Pasal 127 ayat (2) dan (3) Undang-undang Nomor 35 Tahun 2009, penyidik tidak menggali pembuktian perkara ini dalam hal untuk menentukan status penyalah guna dari terdakwa Yohanes Salim pgl. Aseng bin Nurtanto Salim. Dalam berkas penyidikan perkara, penyidik tidak ada meminta keterangan para saksi, terdakwa, ahli maupun alat bukti surat untuk mengetahui status terdakwa Yohanes Salim pgl. Aseng bin Nurtanto Salim, apakah sebagai penyalah guna biasa, pecandu, korban penyalah guna narkotika atau terlibat dalam peredaran gelap narkotika.
Dengan tidak diterapkannya ketentuan Pasal 54, Pasal 103, Pasal 127 ayat (2) dan (3) Undang-undang Nomor 35 Tahun 2009 Tentang Narkotika oleh penyidik, seharusnya penuntut umum dapat melakukan pra penuntutan dengan mengembalikan berkas penyidikan perkara tersebut kepada penyidik Polresta Padang dengan petunjuk agar penyidik melengkapi bukti-bukti penyidikan dengan menelusuri status terdakwa, apakah termasuk pengguna narkotika biasa, pecandu atau korban penyalahgunaan. Berdasarkan keterangan dari penuntut umum perkara ini, tidak diberikannya petunjuk kepada penyidik untuk menentukan status terdakwa sebagai penyalah guna biasa, pecandu atau korban penyalahgunaan narkotika, adalah karena penuntut umum berpedoman kepada Surat Edaran Mahkamah Agung RI (SEMA) Nomor: 04 Tahun 2010 Tanggal 7 April 2010 Tentang Penempatan Penyalahgunaan, Korban Penyalahgunaan dan Pecandu Narkotika Ke Dalam Lembaga Rehabilitasi Medis dan Rehabilitasi Sosial, pada poin 2 huruf $b$ pada pokoknya menyatakan klasifikasi penyalah guna yang dapat ditempatkan pada Lembaga Rehabilitasi adalah ketika tertangkap tangan, berat barang bukti narkotika jenis shabu yang ditemukan ketika ditangkap tidak melebihi 1 (satu) gram. Apabila dikaitkan dengan jumlah barang bukti shabu yang ditemukan pada perkara ini, berat bersih barang bukti yang ditemukan adalah 4,09 gram (empat koma nol sembilan gram), sehingga berdasarkan Surat Edaran Mahkamah Agung RI 
Rikhi Benindo Maghaz: Permasalahan Penuntutan Terhadap Pelaku Penyalah Guna...

(SEMA) Nomor: 04 Tahun 2010 Tanggal

7 April 2010, terdakwa tidak tepat dikatakan sebagai penyalah guna, karena berat barang bukti narkotika jenis shabu lebih dari 1 gram. Alasan lain dari penuntut umum perkara ini adalah berdasarkan fakta yang terdapat dalam perkara ini, barang bukti narkotika jenis shabu tersebut merupakan barang yang di titip oleh seseorang yang bernama Sipayung Pgl. Payung (DPO), dalam hal ini penuntut umum telah menemukan bukti permulaan yang menyatakan terdakwa terkait dalam peredaran gelap narkotika.

Bahwa alasan penuntut umum yang mendasari kepada SEMA Nomor: 04 Tahun 2010 Tanggal 7 April 2010 dan analisa penuntut umum yang menyatakan bahwa terdakwa terlibat dalam peredaran gelap narkotika, sehingga tidak diperlukan lagi menggali bukti-bukti lain untuk mengetahui status dari terdakwa, hal ini tidak tepat dalam hal upaya menentukan status terdakwa Yohanes Salim pgl. Aseng bin Nurtanto Salim, sehingga tidak terdapat fakta-fakta untuk menentukan apakah Yohanes Salim pgl. Aseng bin Nurtanto Salim termasuk pencandu atau korban penyalah guna narkotika. Kondisi ini jelas merugikan Yohanes Salim pgl. Aseng bin Nurtanto Salim, karena apabila ternyata dirinya merupakan pecandu atau korban penyalah guna narkotika, maka ia berhak mendapatkan rehabilitasi.

Ketidakcermatan penuntut umum dalam menerapkan ketentuan Undangundang Nomor 35 Tahun 2009 Tentang
Narkotika pada perkara ini, berdampak dalam penerapan dakwaan pada perkara ini. Penuntut umum menerapkan dakwaan subsidaritas, dengan Pasal 114 ayat (1), subsidiair dan Pasal 112 ayat (1), lebih subsidiair Pasal 127 ayat (1) huruf a.

Penuntut umum pada perkara ini dari awal telah menilai terdakwa Yohanes Salim pgl. Aseng bin Nurtanto Salim bukan sebagai penyalah guna biasa, tetapi dinilai telah terlibat dalam peredaran gelap narkotika, mengakibatkan penerapan Pasal 127 ayat (1) huruf a sebagai pelaku penyalah guna narkotika golongan I hanya sebagai pelapis saja. Dikatakan sebagai pasal pelapis saja, adalah fakta penyidikan yang diakomodir penuntut umum di tahap penuntutan dan diajukan ke persidangan adalah perbuatan terdakwa dalam hal menerima titipan 1 paket narkotika jenis shabu dan menyimpannya di rumah terdakwa, padahal pada faktanya (berdasarkan keterangan para saksi dan keterangan terdakwa) ia ditangkap ketika sedang menggunakan narkotika jenis shabu tersebut. Adapun fakta yang menerangkan barang bukti narkotika jenis shabu tersebut adalah titipan dari orang lain, hanya berdasarkan keterangan terdakwa semata yang tidak didukung oleh alat bukti lain.

Implikasi tidak dioptimalkannya penerapan ketentuan Undang-undang Narkotika Nomor 35 Tahun 2009 terhadap penyalah guna oleh penuntut umum, berdampak kepada pembuktian perkara ini di persidangan. Bahwa pada persidangan perkara ini, penuntut umum 
telah menuntut terdakwa dengan dakwaan subsidiair Pasal 112 ayat (1) Undangundang Nomor 35 Tahun 2009. Alasan penuntut umum membuktikan dakwaan subsidiair tersebut adalah karena berdasarkan fakta persidangan penuntut umum menilai ketika saksi-saksi dari anggota Polresta Padang melakukan penggeledahan di rumah terdakwa, ditemukan 1 (satu) buah kotak rokok merk $U$ Mild warna putih biru berisikan 1 (satu) paket besar shabu, 1 (satu) buah bong terbuat dari botol plastik berisikan air terpasang pipet kaca pirek dan karet kompeng, 1 (satu) buah mencis dan 1 (satu) buah kaca pirek di atas meja rumah terdakwa dan pada saat ditanyakan oleh petugas kepolisian terdakwa mengakui bahwa semua barang bukti tersebut adalah milik dan dalam penguasaan terdakwa yang diperoleh terdakwa dari Sipayung (DPO). Bahwa terdakwa dituntut dengan pidana penjara selama 8 (delapan) tahun dan pidana denda sebesar Rp.1.000.000.000,- (satu milyar rupiah) subsidiair 3 (tiga) bulan penjara. Kemudian berdasarkan pembuktian penuntut umum dalam perkara ini, majelis hakim memutus terdakwa dengan pasal dakwaan subsidiair sesuai dengan tuntutan penuntut umum, namun dengan pidana penjara selama 7 (tujuh) tahun dan Pidana Denda sebesar Rp.1.000.000.000,(satu milyar rupiah) subsidiair 3 (tiga) bulan penjara.

\section{Analisa pelaksanaan penuntutan perkara Tindak Pidana Penyalah Guna Narkotika di Kejaksaan Negeri Padang}

Berdasarkan uraian terhadap penanganan perkara tindak pidana narkotika dari 3 sampel perkara tersebut, dapat dianalisa bahwa penuntut umum pada Kejaksaan Negeri Padang, secara materil selalu menerapkan dakwaan berbentuk subsidaritas, walaupun pada kenyataannya terdapat perbedaan dalam pembuktian. Dari ketiga perkara tersebut, pada prinsipnya terdapat kesamaan dalam perbuatan para terdakwa, yakni sebelum terdakwa ditangkap, terdakwa menggunakan narkotika terlebih dahulu. Namun demikian dalam pembuktian perkara ini terdapat perbedaan terhadap pasal yang dibuktikan oleh penuntut umum. Kondisi ini menyebabkan penegakan hukum terhadap perkara narkotika, khususnya terhadap pelaku penyalah guna narkotika tidak berjalan maksimal, yang ditandai dengan masih maraknya perkara narkotika di Kota Padang.

Penelitian berkas penyidikan oleh penuntut umum pada Kejaksaan Negeri Padang pada tahap pra penuntutan tidak dilakukan secara optimal dalam upaya menerapkan ketentuan Pasal 54, Pasal 103, Pasal 127 ayat (2) dan (3) Undangundang Nomor 35 Tahun 2009 dalam penanganan perkara tindak pidana penyalahgunaan narkotika. Kondisi ini dapat merugikan pelaku, terutama dalam penerapan pemidanaan. Kerugian nyata dari pelaku penyalah guna narkotika yang 
Rikhi Benindo Maghaz: Permasalahan Penuntutan Terhadap Pelaku Penyalah Guna...

merupakan pecandu, adalah apabila tidak diterapkan rehabilitasi, maka penempatannya di sel tahanan dan di penjara adalah hal yang sangat tidak tepat. Situasi ini menyebabkan pelaku pecandu narkotika tidak akan sembuh dari ketergantungannya, bahkan ia dapat bertemu dengan para narapidana pengedar narkotika atau narapidana penyalah guna narkotika lainnya di dalam Lembaga Pemasyarakatan. Hal ini dapat menyebabkan narapidana pecandu narkotika tersebut, sulit untuk keluar dari ketergantungannya dengan narkotika. Hal ini menjadi penyebab maraknya terjadi penyelundupan narkotika di Lembaga Pemasyarakatan.

Permasalahan tidak optimalnya penuntut umum dalam upaya menerapkan ketentuan Pasal 54, Pasal 103, Pasal 127 ayat (2) dan (3) Undang-undang Nomor 35 Tahun 2009 dalam penanganan perkara tindak pidana penyalahgunaan narkotika, berdampak kepada penyusunan surat dakwaan. Bahwa penuntut umum pada Kejaksaan Negeri Padang selalu mendakwa pelaku penyalah guna narkotika dengan ketentuan yang jauh lebih berat, yaitu dengan pasal 111 atau pasal 112 Undang-undang Nomor 35 Tahun 2009 dengan ancaman hukuman penjara minimal 4 tahun, maksimal 12 tahun, dan denda minimal $\mathrm{Rp}$ 800.000.000,- (delapan ratus juta rupiah), maksimal Rp.8.000.000.000,- (delapan milyar rupiah). Padahal ketentuan pidana untuk pelaku penyalah guna narkotika telah diatur pada Pasal 127 Undangundang Nomor 35 Tahun 2009 dengan ancaman pidana penjara untuk narkotika golongan I paling lama 4 tahun, golongan II paling lama 2 tahun dan golongan III dengan paling lama 1 tahun, tanpa adanya ancaman pidana denda, bahkan apabila pelaku penyalah guna narkotika tersebut adalah pecandu, maka hakim dapat memberikan putusan berupa rehabilitasi.

Bahwa dengan dicantumkannya pasal-pasal yang lebih berat kepada pelaku tindak pidana penyalah guna narkotika, baik oleh penyidik, penuntut umum hingga ke tahap persidangan, secara teori hukum pembuktian telah merugikan pelaku penyalah guna narkotika, karena telah diterapkannya ketentuan pasal yang tidak tepat. Bahwa pembuktian yang berarti bukti yang cukup untuk memperlihatkan kebenaran suatu peristiwa, sehingga pembuktian bermakna suatu perbuatan untuk membuktikan suatu kebenaran, melaksanakan, menandakan, menyaksikan serta meyakinkan (M. Yahya Harahap, 2012: 252-255). Pembuktian pada dasarnya tidak hanya di persidangan semata. Pembuktian kesalahan seseorang pada dasarnya sudah dimulai di tahap penyidikan. Penentuan seseorang sebagai tersangka di tingkat penyidikan, adalah berdasarkan bukti permulaan yang cukup. Berdasarkan bukti permulaan cukup itulah kemudian penuntut umum di tahap penuntutan menentukan perkara tersebut layak atau tidak diajukan ke persidangan. Bahkan sebenarnya aspek hukum pembuktian asasnya sudah dimulai sejak tahap penyelidikan perkara pidana. Tahap pembuktian sudah dimulai dari tahap 
penyelidikan, karena pada tahap ini penyelidik bertugas untuk mencari dan menemukan sesuatu peristiwa yang diduga sebagai tidak pidana guna dapat atau tidaknya dilakukan penyidikan (Syaiful Bakhri, 2009: 37). Moeljatno dalam pandangannya terhadap putusan, menyatakan bahwa agar putusan hakim menjadi putusan yang tepat, maka hakim tidak dapat memakai suatu keadaan yang abstrak dan umum, terhadap perkara tertentu diperlukan penelitian yang rapi dan konkret, agar seluruh fakta yang mungkin diketahui secara objektif di waktu itu, dan berpengaruh terhadap akibat suatu kejadian, ikut dipertimbangkan sehingga dapat diketahui batasan antara syarat dan musabab (Moeljatno, 2008: 105).

Penyusunan dakwaan terhadap perkara tindak pidana penyalahgunaan narkotika yang selalu disusun secara subsidaritas, dengan menempatkan pasal tindak pidana penyalahgunaan narkotika sebagai pasal yang paling terakhir, menandakan penuntut umum pada Kejaksaan Negeri Padang tidak dapat menerapkan aspek hukum pembuktian dengan tepat. Fungsi penuntut umum sebagai dominius litis (pengendali perkara), tidak hanya menerima begitu saja pasal-pasal yang diajukan penyidik dalam berkas penyidikan. Kewenangan penuntut umum dalam meneliti penyidikan perkara tindak pidana di tahap pra penuntutan, seharusnya dapat menerapkan ketentuan-ketentuan yang diatur dalam menangani perkara tindak pidana penyalahgunaan narkotika. Hal yang mendasar dalam penanganan perkara tindak pidana penyalahgunaan narkotika, adalah penerapan ketentuan Pasal 54, 103 dan Pasal 127 ayat (2) dan (3) Undangundang Nomor 35 Tahun 2009, kemudian ketentuan dari PERJA Nomor: 029/A/JA/12/2015, sehingga apabila penuntut umum dengan benar menerapkan ketentuan tersebut dengan tepat maka penerapan dakwaan yang berlapis-lapis terhadap terdakwa tindak pidana penyalahgunaan narkotika tidak akan terjadi.

Dari 3 sampel perkara tersebut, terdapat cara pembuktian yang bervariatif. Hal ini berujung kepada pembuktian dan vonis dari majelis hakim. Hal yang paling nyata terlihat adalah pada perkara atas nama Mardianto pgl. Anto dan perkara atas nama Yohanes Salim pgl. Aseng. Apabila dikaitkan dengan Surat Edaran Mahkamah Agung RI (SEMA) Nomor: 04 Tahun 2010 dan Peraturan Jaksa Agung Nomor: 029/A/JA/12/2015, seharusnya terdakwa Mardianto pgl. Anto dibuktikan dengan pasal yang sama diterapkan kepada terdakwa Yohanes Salim pgl. Aseng, hal ini dilihat dari berat barang bukti narkotika yang ditemukan dari terdakwa, seharusnya tidak dikatakan sebagai pelaku penyalah guna narkotika.

Dengan dicantumkannya pasal-pasal yang lebih berat dalam pasal dakwaan penuntut umum, dapat merugikan si pelaku, karena apabila pelaku tindak pidana penyalah guna narkotika tersebut terbukti bersalah dengan Pasal 127 Undang-undang Nomor 35 Tahun 2009, maka seharusnya pelaku tindak pidana 
Rikhi Benindo Maghaz: Permasalahan Penuntutan Terhadap Pelaku Penyalah Guna...

penyalah guna narkotika tersebut tidak dapat diterapkan penahanan pada dirinya, baik di tingkat penyidikan hingga ke tingkat persidangan. Hal ini karena ancaman pidana Pasal 127 Undangundang Nomor 35 Tahun 2009 paling lama hanya 4 (empat) tahun penjara, sehingga berdasarkan ketentuan Pasal 21 ayat (4) huruf a KUHAP, yang pada pokoknya menyatakan penahanan hanya dapat dikenakan terhadap terdakwa atau terdakwa yang melakukan tindak pidana dengan ancaman pidana penjara lima tahun atau lebih. Sedangkan dalam Pasal 21 ayat (4) huruf $b$ diperinci mengenai tindak pidana tertentu yang dapat dilakukan penahanan walaupun ancaman pidananya tidak sampai 5 (lima) tahun penjara, dalam hal ini tindak pidana penyalah guna narkotika yang diatur dalam Undang-undang Narkotika tersebut tidak diatur dalam Pasal 21 ayat (4) huruf b KUHAP sebagai pasal yang dapat dilakukan penahanan, sehingga penahanan yang dikenakan terhadap terdakwa atau terdakwa di luar tindak pidana yang ditentukan dalam Pasal 21 ayat (4) KUHAP adalah tindakan yang bertentangan dengan undang-undang (M. Yahya Harahap: 2012). Dalam hal ini apabila dilakukan penahanan kepada pelaku yang benar-benar hanya melakukan penyalah guna narkotika atau lazim disebut sebagai pengguna saja, bertentangan dengan asas due process of law. Due process of law dalam system peradilan pidana adalah sebagai suatu proses hukum yang baik, benar dan adil. Sehingga penahanan yang dikenakan terhadap terdakwa atau terdakwa di luar tindak pidana yang ditentukan dalam Pasal 21 ayat (4) KUHAP adalah tindakan yang bertentangan dengan undang-undang (Moeljatno, 2008: 55).

Berdasarkan teori hukum pembuktian dalam hal untuk membuktikan tentang benar tidaknya terdakwa melakukan perbuatan yang didakwakan, merupakan bagian yang terpenting dalam proses Hukum Acara Pidana. Berakibat fatal jika pelaku yang didakwa melakukan tindak pidana, namun di persidangan ia dibuktikan tidak sesuai dengan perbuatannya. Dalam Hukum Acara Pidana, kebenaran materil adalah tujuan dari pembuktian suatu perkara pidana. Apabila dilihat dari fakta penanganan perkara tindak pidana penyalahgunaan narkotika di Kejaksaan Negeri Padang, dengan tidak diterapkannya secara optimal oleh penuntut umum ketentuan Undang-undang Nomor 35 Tahun 2009 dalam hal penanganan perkara penyalahgunaan narkotika, mengakibatkan putusan hakim perkara ini tidak menemukan kebenaran materil. Misalnya pada perkara terdakwa Yohanes Salim pgl. Aseng bin Nurtanto, kebenaran materil yang dimaksud dalam perkara ini adalah, pada faktanya terdakwa ditangkap ketika sedang menggunakan narkotika jenis shabu dan urine terdakwa juga positif mengandung narkotika jenis shabu. Artinya pembuktian penuntut umum dan majelis hakim perkara ini yang menyatakan terdakwa terbukti menguasai atau menyimpan narkotika jenis shabu, secara materil tidak sesuai dengan sikap batin dan fakta perbuatan terdakwa. 
Bahwa apabila dalam perkara Yohanes Salim pgl. Aseng bin Nurtanto penuntut umum berupaya mencari kebenaran materil untuk menentukan status terdakwa apakah termasuk penyalah guna biasa, terlibat peredaran gelap narkotika atau hanya korban penyalahgunaan narkotika, maka arah pembuktian dan pemidanaan yang dijatuhkan kepada terdakwa akan mendekati kepada sikap batin dan niat terdakwa. Dilihat dari fakta perbuatan terdakwa pada perkara ini, penuntut umum sangat perlu mencari bukti-bukti untuk menentukan status penyalah guna terdakwa, sehingga dapat diketahui tujuan terdakwa Yohanes Salim pgl. Aseng bin Nurtanto Salim menerima titipan 1 paket narkotika jenis shabu tersebut. Dalam hal ini penuntut umum tidak menggali apakah terdakwa Yohanes Salim pgl. Aseng bin Nurtanto Salim menerima keuntungan materi dari tindakannya menerima titipan paket shabu tersebut, sehingga tidak dapat ditentukan secara jelas keterlibatan terdakwa dalam peredaran gelap narkotika.

Apabila dikaitkan dengan tindakan terdakwa yang menggunakan sebagian narkotika jenis shabu, penuntut umum perlu mengetahui apakah terdakwa Yohanes Salim pgl. Aseng bin Nurtanto Salim dalam keadaan kecanduan terhadap narkotika jenis shabu, sehingga penuntut umum seharusnya dapat melakukan asesmen kepada terdakwa Yohanes Salim pgl. Aseng bin Nurtanto Salim. Dalam penanganan perkara ini, penuntut umum dan majelis hakim terkesan "bermain aman" dengan menyatakan terdakwa terbukti dalam hal menguasai atau menyimpan narkotika jenis shabu. Permasalahan inilah yang menyebabkan Pasal 112 ayat (1) dan Pasal 111 ayat (1) sebagai "pasal keranjang sampah" atau "pasal karet", karena pasal ini dinilai tidak memenuhi asas lex certa dan asas lex stricta (Yurisprudensi Mahkamah Agung RI Nomor 1071 K/Pid.Sus/2012).

Proses hukum akan tercipta apabila masing-masing institusi penegak hukum, tidak semata melaksanakan kewenangannya sesuai dengan yang telah diatur, namun semua hak seseorang yang disangka atau didakwa dapat dipenuhi sebagaimana ketentuan yang ada, serta asas-asas dan prinsip-prinsip yang melandasi proses hukum yang adil tersebut dapat diterapkan, meskipun asas atau prinsip tersebut tidak merupakan peraturan hukum positif (Muladi, 1998: $5)$.

Berkaitan dengan teori keadilan, filosof Aristoteles memperkenalkan teori etis dalam bukunya yang berjudul "Retorica dan "Ethicanikomachea. Teori ini berpendapat bahwa tujuan hukum itu semata-mata untuk mewujudkan keadilan. Keadilan di sini adalah ins suum quique tribuere, yang artinya memberikan kepada setiap orang apa yang menjadi bagian atau haknya (Dudu Duswara, 2002: 23). Teori tersebut menerangkan bahwa apabila seseorang melakukan kesalahan, maka keadilan secara korektif berupaya memberi kompensasi yang memadai bagi pihak yang dirugikan. Jika suatu kejahatan dilakukan, maka 
Rikhi Benindo Maghaz: Permasalahan Penuntutan Terhadap Pelaku Penyalah Guna...

hukuman yang sepantasnya perlu diberikan pada si pelaku. Prinsip-prinsip itu adalah hukuman harus memperbaiki kejahatan, ganti rugi harus memperbaiki kerugian dan memulihkan keuntungan yang tidak sah.

Dalam menentukan pelaku tindak pidana narkotika, harus melihat buktibukti yang terkuat dalam suatu tindak pidana, hal ini terkait dengan istilah actus reus dan mens rea dari si pelaku dalam melakukan perbuatannya tersebut. Dalam prakteknya, penerapan pasal 111 atau 112 Undang-undang Nomor 35 Tahun 2009 dalam dakwaan penuntut umum kepada pelaku penyalah guna narkotika tentu akan merugikan terdakwa, karena apabila niat dan sikap batin terdakwa tersebut nyata-nyata hanya untuk menggunakan narkotika saja, seharusnya terdakwa haruslah diterapkan Pasal 127 Undangundang Nomor 35 Tahun 2009, bahkan apabila tindakan terdakwa karena pengaruh kecanduan, maka terdakwa pada dasarnya punya hak untuk mendapatkan rehabilitasi. Supaya tidak terjerat lagi dalam lingkungan yang membahayakan masa depannya, diperlukan konsep penghukuman yang menimbulkan sifat jera, disertai dengan program rehabilitasi, yaitu pendidikan/pembinaan (Asrianto Zainal, 2013: 15). Namun demikian, permasalahan lain yang dihadapi dalam penerapan tindakan rehabilitasi terhadap pelaku pecandu narkotika tidak hanya dari aparat penegak hukum, tetapi kurangnya fasilitas rehabilitasi disetiap daerah, menjadi kendala yang dialami dalam menuntut rehabilitasi (Fredi Wahyu Putra Adhyaksa, 2017: 7).

Penjatuhan hukuman atau pemidanaan bagi pelaku tindak pidana narkotika, juga merupakan kontrol sosial bagi kehidupan masyarakat. Bahwa putusan hakim yang tepat dan memenuhi rasa keadilan masyarakat, pada perkara tindak pidana penyalahgunaan narkotika, akan meningkatkan efektifitas pemberantasan peredaran gelap narkotika tersebut. Apabila kembali pada tujuan hukum pidana secara sederhana adalah untuk menemukan kebenaran materil. (Bambang Waluyo, 2004: 89)

\section{KESIMPULAN}

1. Untuk membahas permasalahan penanganan perkara tindak pidana narkotika pada Kejaksaan Negeri Padang, telah diambil sampel 3 perkara yang telah ditangani oleh penuntut umum pada Kejaksaan Negeri Padang, yakni pada perkara atas nama terdakwa Mardianto Pgl. Anto, Eka Tyza Effriyandi, SP Pgl. Andi dan Yohanes Salim Pgl. Aseng. Dari hasil penelitian terhadap ketiga perkara tersebut, penuntut umum pada Kejaksaan Negeri Padang tidak pernah menempatkan Pasal 127 berdiri sendiri (dakwaan tunggal), tetapi selalu disertai atau dengan pasal lain, terutama pasal 111 (untuk jenis tanaman) atau pasal 112 (untuk jenis bukan tanaman) yang merupakan pasal yang mengatur sebagai pemilik, yang menyimpan atau yang menguasai narkotika. Ketiga perkara ini dipilih, karena ketiga perkara 
tersebut memiliki konstruksi kasus yang sama, namun ditangani dengan cara yang berbeda-beda oleh penuntut umum di Kejaksaan Negeri Padang, hal ini berdampak kepada tuntutan pidana dan putusan pidana kepada pelaku.

2. Bahwa penuntut umum pada Kejaksaan Negeri Padang dalam penerapan ketentuan materil untuk kepentingan pembuktian perkara tindak pidana penyalahgunaan narkotika sebagaimana yang diatur pada Pasal 54, Pasal 103 dan Pasal 127 ayat (1), ayat (2) dan ayat (3) Undang-undang Nomor 35 Tahun 2009, tidak diterapkan secara cermat oleh penuntut umum Kejaksaan Negeri Padang. Penuntut umum hanya menerima status pelaku sebagaimana yang telah di sangkakan oleh penyidik dalam berkas penyidikan perkara tersebut, tanpa menggali bukti-bukti materil mengenai status pelaku penyalah guna narkotika tersebut, sebagai penyalah guna biasa, pecandu, korban penyalahgunaan atau terlibat dalam peredaran gelap narkotika, tanpa menggali status pelaku, sehingga secara materil tidak dapat ditentukan pelaku tersebut apakah termasuk penyalah guna narkotika biasa, pecandu atau korban penyalahgunaan narkotika. Selain itu, penuntut umum, tidak pernah menerapkan dakwaan tunggal Pasal 127 kepada pelaku tindak pidana penyalah guna, alasan penuntut umum adalah untuk alasan penahanan. Karena apabila hanya diterapkan dakwaan tunggal Pasal 127, maka pelaku tindak pidana penyalah guna narkotika tidak dapat ditahan sebagaimana ketentuan Pasal 21 ayat (4) KUHAP, hal ini jelas merugikan pelaku penyalah guna narkotika, terutama bagi pecandu atau korban penyalahgunaan, sebab terhadap mereka seharusnya ditempatkan di Lembaga Rehabilitasi.

\section{UCAPAN TERIMAKASIH}

Penulis kepada semua pihak yang telah mendukung penulisan artikel ini, terutama kepada Bapak Prof. Dr. Elei Danil, SH., MH dan Dr. Sukanda Husin, SH. LLM selaku dosen pembimbing tesis dan penulisan artikel ini, serta kepada tenaga pengajar dan teman-teman mahasiswa Program Pascasarjana Fakultas Hukum Universitas Andalas.

\section{DAFTAR KEPUSTAKAAN}

\section{Buku-buku:}

Bambang Waluyo, Pidana dan Pemidanaan, Sinar Grafika, Jakarta, 2004.

Dudu Duswara Machmudin, Ilmu Hukum Sebuah Sketsa, Refika Aditama, Bandung, 2000.

Eddy. OS. Hiariej, Prinsip-prinsip Hukum Pidana, Yogyakarta, Cahaya Atma, 2016.

F. Sugeng Istanto, Penelitian Hukum, CV. Ganda, Yogyakarta, 2005.

M. Yahya Harahap, Pembahasan Permasalahan dan Penerapan KUHAP Penyidikan dan Penuntutan, Sinar Grafika, Jakarta, 2000. 
Rikhi Benindo Maghaz: Permasalahan Penuntutan Terhadap Pelaku Penyalah Guna...

------, Pembahasan Permasalahan dan Penerapan KUHAP Pemeriksaan Sidang Pengadilan, Banding, Kasasi dan Peninjauan Kembali, Edisi Kedua, Sinar Grafika, Jakarta, 2012.

Moeljatno, Asas-Asas Hukum Pidana, Jakarta, Rieneka Cipta, 2008.

Jurnal:

Asrianto Zainal, Penegakan Hukum Terhadap Kejahatan Narkotika Ditnjau Dari Aspek Kriminologi, Jurnal Al Ad'li, Vol.6, 2013.

Cardiana Harahap, Peranan Kejaksaan Dalam Melakukan Penuntutan Tindak Pidana Narkotika, USU Law Jurnal, Vol.4, 2017.

Fredy Wahyu Putra Adhyaksa, Implementasi Pasal 54 Undangundang Nomor 35 Tahun 2009 Tentang Narkotika Terhadap Penuntutan Pelaku Tindak Pidana Narkotika, Jurnal Hukum Universitas Brawijaya, 2017.

Gilang Fajar Shadiq, Penegakan Hukum Terhadap Tindak Pidana Narkotika New Pshycoactive Substance Berdasarkan Undang-undang Nomor 35 Tahun 2009 Tentang Narkotika, Jurnal Wawasan Yuridika, Vol.1, 2017.

Wisnu Djati Dewangga, Penegakan Hukum Tindak Pidana Narkotika Dengan Pelaku Angota Kepolisian, Jurnal Jurisprudence, Vol.4, 2014.

\section{Peraturan Perundang-Undangan:}

Kitab Undang-undang Hukum Pidana (KUHP) (Lembaran Negara Republik Indonesia Tahun 1958 Nomor 127).

Undang-undang Nomor 8 Tahun 1981 Tentang Kitab Undang-undang Hukum Acara Hukum Pidana (KUHAP) (Lembaran Negara Republik Indonesia Tahun 1981 Nomor 76, Tambahan Lembaran Negara Republik Indonesia Nomor 3209).

Undang-undang Nomor 35 Tahun 2009 Tentang Narkotika (Lembaran Negara Republik Indonesia Tahun 2009 Nomor 143).

Undang-undang Nomor 16 Tahun 2004 Tentang Kejaksaan Republik Indonesia (Lembaran Negara Tahun 2004 Nomor 67).

Peraturan Jaksa Agung RI (PERJA) Nomor: 029/A/JA/12/2015 Tentang Petunjuk Teknis Penanganan Pecandu Narkotika dan Korban Penyalahgunaan Narkotika ke Lembaga Rehabilitasi (Berita Negara Republik Indonesia Tahun 2015 Nomor 1961). 